\title{
Discrete-Item Approach Model in the Teaching of Listening for Basic Level Learners of Indonesian Language for the Speakers of Other Languages
}

\author{
Nais Ambarsari ${ }^{1}$, Yeti Mulyati2,* \\ ${ }^{1}$ Language Center UPI \\ ${ }^{2}$ Universitas Pendidikan Indonesia \\ ${ }^{*}$ Corresponding author. Email: yetimulyati@upi.edu
}

\begin{abstract}
Listening skills are an important part of communication and are the basis of learning a second or foreign language. The time estimated in adult human communication activities is $45 \%$ for listening, 30\% for speaking, $16 \%$ for reading, and $9 \%$ for writing (Rivers \& Temperley, 1978). Listening skills for foreign language learners are very important skills because they are needed to master a foreign language well. However, listening skills are skills that are still difficult for foreign learners to learn according to the interviews with teachers of a Language Center in a university in Indonesia. The research method used was an experimental model using a variation of the interrupted time-series design. The analysis shows that there is a significant difference between the ability to listen to responses in writing and orally before using the discreteitem approach and after using the discrete-item approach.
\end{abstract}

Keywords: Experimental model, Listening skills, the discrete-item approach training method

\section{INTRODUCTION}

Learning Indonesian language among the speakers of other languages (BIPA) is seen as more of a learner factor. For basic level, the need is to listen extensively for the general information. In particular, the type for listening to socialize is known as listening to social interactions. This skill is very close to speaking skills so that speaking and listening learning materials are related to each other (Kusmiatun, 2016 p. 67). The research took place at a Language Center of a university in Indonesia. Based on the explanation above, the researcher views that research is needed to try out a teaching method to improve listening skills in learning basic BIPA. This study aims to determine whether the teaching model of the discrete-item approach affects the results of listening skills or not. Nord and Paul (1980) stated

Some people now believe that learning a language is not just learning to talk, but rather that learning a language is building a map of meaning in the mind. These people believe that speaking may indicate that the language is learned, but they do not believe that practice in speaking is the best way to build up this "cognitive" map in the mind. To do this, they feel, the best method is to practice meaningful listening".

According to Brown (1980), the discrete approach is based on the theory of structuralism in linguistics and the theory of behaviourism in psychology. The basic concept of the two theories states that a whole form can be broken down into certain parts. About the learning process, this theory adopts the notion that each subaspect of a language can be taught and tested separately and independently, regardless of the overall context and the actual language use situation. Flowerdew and Miller (2005) stated that the audio-lingual approach leads to what is called a discrete-item approach in learning. This approach as an audio-lingual approach is focused on learning grammar about clear "understanding". Muliastuti (2017 p. 17) stated that learning BIPA is different from learning Indonesian as the first language (B1). Learning BIPA 1 is more complex and complicated, partly because foreign students studying BIPA can come from various countries. What is meant 
by foreign students here are students who (1) have a foreign nationality (non-Indonesian) and (2) speak their mother tongue instead of Indonesian. According to Charles (2006), the reasons for learning to listen is that We have for too long underrated the importance of listening. We have been assured to to believe that listening skill will develop.

\section{METHOD}

This research in this study followed the design of experimental research conducted by using an interrupted time-series experimental model, which is a model that tests an idea (or practice or procedure) to determine whether the idea affects the results or the dependent variable (Creswell, 2015 p. 576). The interrupted time series of experimental model is a model that focuses on determining the cause and effect of the independent and dependent variables.

Researchers used a variation of the interrupted timeseries design. This procedure involved examining a group, obtaining multiple pre-test measures over a specified period time, administering the intervention, and then measuring the outcome (or post-test) multiple times. Data analysis was in the form of examining the different scores between pre-test and post-test scores or post-test scores only and using pre-test as a covariate (Creswell, 2015 p. 615).

The table describes the research flow using the time series method. The first step was selecting participants for the group. After this part, researcher did first pre-test measurements or observations and then do second pretest measurements or observations until third pre-test measurements or observations. After the part of pre-test was done, the researcher did the intervention. After that, the process moved to the post test. The first activity was post-test measurements or observations, and then followed by the second post-test measurements or observations and the third post-test measurements or observations.

\section{RESULTS AND DISCUSSION}

The first thing to do is to calculate the reliability of the three raters to determine the objectivity and subjectivity of the data. From the calculation results of each test, it was found that the reliability value between the weights for the pre-test listening to the response in writing was high. After the reliability test, the normality test of significant values was carried out towards listening to the responses in writing with a normal distribution and the significant values after listening to the responses in writing that were normally distributed. The results show that the data were normally distributed. The next step was to test the homogeneity using parametric analysis. Based on the results of the homogeneity test, the significance value of the initial test and the final test shows that the significance value of listening to the written response> 0.05 was 0.275 so that the data were homogeneous.

To find out the differences in students' abilities in listening to responses in writing before and after the implementation of the training model, the discrete-item approach can be seen from the results of hypothesis testing. Hypothesis testing was done to prove the application of the discrete-item approach to learning Listening Responses in Writing. Based on the calculation of the hypothesis test, the sig value was obtained, that was, (2-tailed) of 0.041, so according to the basis for decision making in the Independent Sample T-Test, it can be concluded that Ho was rejected and $\mathrm{Ha}$ was accepted, which means that there was a difference between the results of the pre-test and post-test listening to the responses in writing before using the training model the discrete-item approach after using the discrete-item approach teaching model.

Based on the results of the analysis, the increase in the ability to listen to the verbal responses of basic level BIPA students at the Language Centre can be seen from the students' ability to reveal information both in the form of main ideas and main information appropriately based on the contents of the reading. This is evidenced

Table 1. Experimental design time-series Design Interrupted Time Series

\begin{tabular}{||l|l|l|l|l|l|l|l|}
\hline $\begin{array}{l}\text { Select } \\
\text { participants } \\
\text { for the } \\
\text { group }\end{array}$ & $\begin{array}{l}\text { Pre-test } \\
\text { measurements } \\
\text { or } \\
\text { observations }\end{array}$ & $\begin{array}{l}\text { Pre-test } \\
\text { measurements } \\
\text { or } \\
\text { observations }\end{array}$ & $\begin{array}{l}\text { Pre-test } \\
\text { measurements } \\
\text { or } \\
\text { observations }\end{array}$ & Intervention & $\begin{array}{l}\text { Post-test } \\
\text { measurements } \\
\text { or } \\
\text { observations }\end{array}$ & $\begin{array}{l}\text { Post-test } \\
\text { measurements } \\
\text { or } \\
\text { observations }\end{array}$ & $\begin{array}{l}\text { Post-test } \\
\text { measurements } \\
\text { or } \\
\text { observations }\end{array}$ \\
& & & & & & \\
& & & & & \\
\hline
\end{tabular}


by the answers given by the learners according to the information contained in the watch. In addition, before the implementation of the discrete-item approach teaching model, students were still not fluent in expressing the results of the study, only one word or two words were mentioned by learners. Although there were still students who were stammering in expressing the information they saw, in general, students had e been able to get rid of the accent of Korean native speakers, namely not using emphasis when expressing words, removing vowels in the vocabulary.

Another improvement in ability is that learners could express information by using sentence structure correctly and clearly. Students were accustomed to overtaking sentences by using the subject. Previously learners only mentioned vocabulary related to the contents of the list. Finally, learners learned a lot of new vocabulary contained in the listening practices and revealed the information on the watch by using the appropriate vocabulary and following the context of the contents of the listening. An example would be to mention price, currency, rupiah, and the bargaining process in a buying and selling situation.

Thus, the ability of learners after the implementation of the discrete-item approach teaching model increased significantly. Besides, students had reached the graduation standard for the listening skills of basic BIPA learners. Those skills included Spelling/repeating words and phrases related to name, address, occupation, country of origin, family, from the utterances they heard. This is evidenced by the material in the first pretest and the first post-test which emphasized the words related to name, country of origin, and family. Then the learners could spell/rephrase words and phrases related to the direction, location, surroundings, and daily activities of the speech they heard. This is evidenced by the students being able to answer correctly about their daily activities regarding the buying and selling process or activities at school.

Based on the results of the analysis, the increase in the ability to listen to the responses in writing of basic level BIPA, students at the Language Centre can be seen from the students' ability to answer the questions given by researchers related to what they had listened. Students had been able to write information in the form of main and supporting ideas, main and additional information appropriately based on the contents of the watch. This is evidenced by the fact that all learners could answer all of the questions correctly according to the contents of the reading. Another increase in ability is the ability to structure sentences. Learners were able to make sentences from the results by using the structure function in sentences, compared to the ability before they were involved in the discrete-item approach teaching model. Although not all learners could write the contents of the watch with the correct sentence structure, in general the students were able to use correct and clear sentence structure.

From the final results of the post-test, it can be seen that there were differences in the scores obtained for the ability to listen to responses in writing and orally. The highest score obtained in listening to responses orally was 12 , while the lowest score was 6 . on the ability to listen to responses orally, the highest score obtained listening to responses orally was 18, while the lowest score was 10. Based on the results of hypothesis testing using the Test, the Independent Sample T-Test with the SPSS above obtained the sig value. (2-tailed) of 0.657 , then according to the basis of decision making in the Independent Sample T-Test, it can be concluded that $\mathrm{Ha}$ was rejected and Ho was accepted, which means that there was no difference between the post-test results listening to the written response and the post-test listening results listening to the response orally after using the discrete-item approach training model.

The listening ability has different parameters for the written category of the spoken category. When the learner could use the sentence structure appropriately when expressing the contents of the reading results, understanding the principles of the discourse being listened to, the learners reached the achievement parameters of Listening in Writing Responses. This is in line with the opinion of Buck (1990) which states that there are four parameters for learners in listening ability, namely in the grammatical knowledge section, including the accuracy of sentence structure, determining conclusions on the results of listening. In the second stage, discourse knowledge includes cohesiveness between sentences/paragraphs and the accuracy of language rules. In the third stage, pragmatic knowledge includes understanding the meaning/meaning of the discourse being listened to and determining the main points of ideas. Besides, the last stage is social knowledge. Watson (2000) argues that the parameters of listening to the response in writing are when the learners can determine the content of the information from the tune.

In the category of listening to the responses orally, listening is more focused on how learners can express the contents of the results of what they are listening to accurately, fluently do not stutter when pronouncing the contents of the results and can use vocabulary according 
to the context of the situation. This is in line with the opinion of Buck (1990) which states that the parameters of listening to the response orally when students can express the results of listening fluently, using intonation, pause, and pressure appropriately. The existence of repeated use of words or pronunciation errors. Besides, learners can determine ideas from the results of listening. The most important thing is that learners avoid dialect elements as teak speakers. This parameter is reinforced by Watson's (2000) opinions indicating that learners must be able to remember what is conveyed correctly.

In this study, the type of listening is focused on is extensive listening. This aims to make students accustomed to listening in social issues in everyday environments. The success of listening instruction is determined by several factors, one of which is the type of materials. This is following Harmer (2007) in classifying listening materials into two types: extensive and intensive listening materials. Extensive discretionary listening can take place outside of the classroom. Therefore, any material that is available outside of the classroom (e.g., radio, TV, personal computer, Internet) can be used for listening extensively. Some of the advantages of extensive listening are that students can use it based on their preferences and they can use as many materials as they want (Harmer, 2007).

Research conducted by using the discrete item approach model aims to focus students on one language skill, namely listening. The ability to listen to the written and oral responses of basic level BIPA students at the Language Centre is very low, so a special approach is needed to improve listening skills. Besides, researchers also want to improve the ability of homogeneous learners (originating from South Korea) when pronouncing letters in Indonesia so that the native speakers' dialect is not too obvious. The results of this study prove that Ur's (1996) theory shows that many learners have difficulty hearing sounds in English because these sounds may not exist in their language. Therefore, it is important to learn to date a unique understanding of the common terms of the target language if the learner is to be an efficient listener.

Robbert and George (2006) have the analysis of variance of scores on the listening tests by treatment groups and show apparent significant differences in gains of listening skills between groups. However, the analysis of covariance by using the listening pre-test as covariant reveals that the indicated gains in listening ability are pre-test effects rather than experimental effects. Implications for listening research are discussed. There is no significant correlation between pre-test and gains in listening found. However, when grouped according to gender, females were found having made significantly greater gains than males.

\section{CONCLUSION}

The discrete-item approach teaching method can improve written and oral listening skills in terms of accuracy in expressing the results of the listening content, the sentence structure used in expressing the results of the listening content, increasing the fluency of the learners in expressing the results of the listening content, and the vocabulary used accordingly.

There is a significant difference between written and oral listening skills before using the discrete-item approach training method and after using the discreteitem approach teaching method. This is evident from the average results before and after being given treatment with the discrete-item approach teaching model, namely, the average pre-test score for listening to writing is 5.9 while the average post-test score for listening and writing is 9.6. In oral writing skills, there is also a significant difference, namely, the mean score of listening pre-tests is 7.1 while the average post-test listening score is 13.7 .

\section{REFERENCES}

Brown, H. D. (1980). Principle of language learning and teaching. London: Longman.

Buck, G. (1990). Assessing listening. Cambridge: Cambridge University.

Charles, E. I. (2006). Activities designed to improve listening skill. Journal of Communication, 4(1), 14-16. doi: 10.1111/j.1460-2466.1954.tb00212.x

Creswell, J W. (2015). Penelitian kualitatif \& desain riset. Yogyakarta: Pustaka Pelajar.

Flowerdew, J., \& Miller, L. (2005). Second language listening, theory and practice. Cambridge: Cambridge University Press.

Harmer, J. (2007) The practice of English language teaching. New York: Pearson Education Limited.

Kusmiatun, A. (2016). Mengenal BIPA (Bahasa Indonesia bagi Penutur Asing) dan pembelajarannya. Yogyakarta: K-Media. 
Muliastuti, L. (2017). Bahasa Indonesia bagi penutur asing (Acuan teori dan pendekatan pengajaran). Jakarta: Yayasan Pustaka Obor Indonesia.

Nord, W. R., \& Paul, P. (1980). A behavior modification perspective on marketing. Journal of Marketing, 44(2), 36-47. doi: 10.2307/1249975

Rivers, W. M., \& Temperley, M. S. (1978). A pratical guide to the teaching of English as a second of foreign language. New York: Oxford University Press.

Robbert, A., \& George, M. (2006). Source of gains in listening skill: Experimental or pre-test experience? Journal of Communication, 22(1), 7076. doi: 0.1111/j.1460-2466.1972.tb00133.x

Watson, C. W. (2000). Multicutularism. BuckhinghamPhiladelphia: Open University Press. 